\title{
Analysis on Quality Management Princi- ples of ISO9000 Standard Series Apply in University Education Quality Manage- ment
}

\author{
Chen Yan-Hua ${ }^{1}$ Li Jing-Jing ${ }^{1}$ Song Jian-Shen ${ }^{2}$ \\ ${ }^{1}$ Northeast Petroleum University School of Marxism Studies, Da Qing, China 163318 \\ ${ }^{2}$ Northeast Petroleum University School of Economics and Management, Da Qing, Chi- \\ na 163318
}

\begin{abstract}
Improve the quality of education is not only the common theme for modern world's university education development, but also an important and urgent problem for Chinese university education. ISO9000 standard series tested by amount of practice of domestic and overseas, it is worth for university to study and introduce in education quality management. The author suggests that it is important to apply the management principles of ISO9000 standard series quality management system but not to mechanically copy the form when reference ISO9000 standard series.
\end{abstract}

Keywords: ISO9000 Standard Series; Education Quality Management; Quality Management Principles

\section{Introduction}

ISO is the English abbreviation of International Organization for Standardization which founded in the mid- to late nineteen forties. ISO9000 standard series is issued by International Organization for Standardization; it is the general name for series standard of quality certification about product, service and other areas. As the quality management system standard and successful model which tested by amount of practice of domestic and overseas, ISO9000 covers aviation, science and technology service, health, information technology and other industries, totally 39 categories. Education service is the 37 th class. This standard has been applied by 150 countries and regions since it launched, and attracted extensive attention of education sectors all over the world. There are 220 universities in America, include Harvard University, applying this standard to certificate the education quality. Our country became the ISO member in 1978, there are some highly selective universities applied ISO9000 series standard, such as Dalian Maritime University and Harbin Institute of Technology, and pass the ISO9000 standard series quality certification.

The author suggests that it is important to apply the eight management principles of ISO9000 standard series quality management system to build the new education quality management system of our country.

\section{Take Students and Social Concerns as Focus Points}

The first important principle of ISO9000 is customers-focused. ISO9000 believes that "organization depends on customers, 
so organization should understand the requirements of customer, fulfill customers' demand and strive to exceed their expectations." University's customers can be defined from three levels: society, employing unit, students and their parents. Take customers' requirement as focus points, universities are demanded to achieve the follows four points:

Firstly, stress students' main role in the bilateral teaching activities and establish the equal relationship between teachers and students.

Secondly, implement the "credit system" in teaching management and give students more autonomy and more option. For example, let students choose the study time, courses, major and teachers, developing their personality and special skills and cultivate their innovation abilities.

Thirdly, strengthen the service conception, that is, "all for students, for the entire students and for all aspect of students". Weaken the regulatory functions to students; strengthen the functions of reference, guiding and service. Fulfill students' thought and need. Strengthen the psychological counseling, study guidance, choose courses guidance, employment guidance and public service.

Fourthly, confer rights to students for participation and supervision teaching management. Such as, develop students' evaluation of teaching activities, allow students enter into the teaching administration and participation in policy decision and management.

University's finial customer is employing unit, so it is necessary for university to know about social employing unit's demand of graduates' quality and universities' teaching job. Adjust the talent cultivation objectives, professional structure, curriculum setting and teaching content according to this demand in order to cultivate the social needed talents.

\section{Leadership Role}

Leaders establish the unified purpose and direction for the organization. They should create and maintain the inner environment which workers can participate in and fulfill the goal of origination. This concept of ISO9000 is especially important in China which has the traditional of "official standard" thought. The leaders should set the quality goals for university development, establish measures, pay close attention to every parts and various stuffs' work, create and maintain the good inner environment which teachers, workers, students could participate fully and improve teaching quality according to universities' properties and characteristics and with the forward-looking vision, forward thinking and action. What's more, all levels leaders of university should full play their personalities, enhance their non-duty influence, and create people oriented, untied, democratic and aggressive atmosphere for university.

\section{Total Involvement}

All levels of personnel are the root of the organization and their full involvement enables their abilities to be used for the organization's benefit. Quality of university teaching comprehensively reflects the working quality of each department, unit and teaching link. It relates to all the teaching staff of the university, which includes leaders, teachers, administrator, teaching assistants and students. For teaching quality management of university, the total involvement principle includes two meanings: one is full participation. Teaching stud and students is the root of the organization. Only they full participate in can university improve the quality of education. The other is "adequately involvement", teaching stuff should have strong sense of quality, professionalism and responsibility, do their 
best and first excellence. Only do this, can make sue the work of school be finished smoothly and in high standards. The quality management system can not be effectively run without total involvement.

\section{Process Approach}

The activities and related resources are managed as a process, can be more efficient to get the desired results. Students need long time to receive higher education, so the improvement of university's education service quality needs several processes. Usually, these processes are not a simple linear in ascending order but a quite complicated three-dimensional network. It is needed for university to finish the following works when apply the process approach:

The first is recognition process, which includes a big process is divided into several sub-processes and defines and decomposes the existed processes. Second, emphasize the primary process. Third, strict the duties and control it. The fourth is pay attention to the interface; the output of the last process is the input of the next process. The interface between the processes is very important. The process approach particularly emphasis the management of the interface and prevent the incompatibility and uncoordinated between the interface which may affect the improvement of education quality. The last is improvement process. Through the measurement and analysis of process, the deficiencies can be discovered and improved. To improve the process on this basis is a basic mean for quality improvement.

\section{System Approach to Management}

Put interrelated processes as a system to indentify, understand and manage will help organizations to improve the effec- tiveness and efficiency for achieving goals. University should implement whole school's teaching quality management. University is a complete system which consisted by multi-department, multi-unit, multi-management level. Various departments interlink each other, affect each other, and play different functions in terms of teaching, research and social services. But teaching work is the primary function for university, and teaching unit and teaching management department are at the heart of school. Each unit and functional department as well as back office should focus on teaching centers to play each quality function. Only each department and unit make concerted efforts and close cooperate, mutual support, and cultivate students through education, management, environment and service, can form the whole school coordinately operated quality management system.

\section{Continual Improvement}

The continuous improvement of the organization's overall performance should be an eternal goal of the organization. Continual improvement is the core concept throughout the ISO9000 standard. Just like a slogan "no best, only better". Continuous quality improvement should be the eternal goal of the school, and continuous improvement is the only way to train the school's core competitiveness. In the knowledge economic period, society and families are increasingly concerned about the quality of education. Universities only improve quality continuously, can they adapt to the change for this demand. On one hand, the accumulated knowledge of the community, including the management knowledge is rapidly growing, the knowledge structure of the employer to employees, especially innovation capability, is increasing. In order to adapt the changes, university should 
constantly improve the courses curriculum, teaching content, teaching way, and teaching management and many other teaching links to improve teaching effectiveness. On the other hand, the competition for resources of students is intensifying, continuous quality improvement can only make sure university to survive and develop in the fierce competition.

\section{Factual Approach to Decision Mak- ing}

Effective decision based on the data and analysis of information. School management improvement requires respect for objective facts, speak with facts and figures. To effectively manage a variety of information, we must first determine the general structure and content of the information needs, and then identify the source of the information, analysis and determine by full using of the obtained information in order to meet the needs of the school management and decisionmaking.

\section{Mutually Beneficial Supplier Rela- tionships}

An organization and its suppliers are interdependent and a mutually beneficial relationship enhances the ability of both to create value. The supplier of the university should include students' sources supplier (secondary school and family), campus infrastructure construction supplier (building enterprises) and teaching equipment supplier (such as computers, laboratory equipment products supplier). The win-win co-existence between university and supplier is not only the core concept of ISO9000 standard, but also the inevitable requirement of university popularization and market-oriented development.

In short, establish and conscious use of the university teaching quality management principles based on the ISO9000 standard will be very beneficial for reforming the traditional teaching quality management concepts and modes and constructing teaching quality assurance system which suitable for our China's university popularization and international development.

\section{References}

[1] Zhang Fushan, Ding qidong. Leadership Guide-Guarantee of Success( Series of ISO9000 Standard, 2000 Edition)[M], Beijing: China Plan Press, 2000.

[2] Wang Zhangbao, Zheng Zhixiang. New Concept of University Teaching Quality Management Based on TQM and ISO9000[J]. Journal of Hefei Polytechnic University(Social Science Edition), 2004(3).

[3] Liu Xiao, ISO9000 Standard Series Quality Management Concept apply in University Teaching Quality Management[D], China Excellent Master Thesis Full-text Database. 